\title{
Hubungan pengetahan kesehatan gigi dan mulut dengan status karies pada pemulung di tempat pembuangan akhir Sumompo Manado
}

\author{
${ }^{1}$ Olivia R. Anggow \\ ${ }^{2}$ Christy N. Mintjelungan \\ ${ }^{2}$ P. S. Anindita \\ ${ }^{1}$ Kandidat Skripsi Program Studi Pendidikan Dokter Gigi Fakultas Kedokteran \\ ${ }^{2}$ Program Studi Pendidikan Dokter Gigi Fakultas Kedokteran \\ Universitas Sam Ratulangi Manado \\ E-mail: olivaanggow@yahoo.com
}

\begin{abstract}
The knowledge of dental and oral health is very essential to the formation of one's actions in the maintenance of his/her dental and oral health. One of the most common oral disease in Indonesian citizen is dental caries. This study was aimed to determine the relationship between the knowledge of oral health status and caries among scavengers in Sumompo Manado. This was a descriptive analytical study with a cross sectional design. There were 78 scavengers aged 18-45 years old as respondents obtained by using purposive sampling method. The results showed that the highest percentages of knowledge about oral health and caries status were in less knowledge with high caries status by an average of $32.1 \%$. The chi-square test obtained a p value of 0.027 . Conclusion: There was a significant relationship between oral health knowledge and caries status of scavengers in Sumompo Manado.
\end{abstract}

Keywords: oral health knowledge, scavengers, caries

\begin{abstract}
Abstrak: Pengetahuan kesehatan gigi dan mulut sangat penting untuk terbentuknya tindakan seseorang dalam pemeliharaan kesehatan gigi dan mulut. Salah satu penyakit gigi dan mulut yang paling banyak diderita masyarakat Indonesia ialah karies gigi. Penelitian ini bertujuan untuk mengetahui hubungan antara pengetahuan kesehatan gigi dan mulut dengan status karies pada pemulung di Tempat Pembuangan Akhir Sumompo (TPA) Manado. Jenis penelitian ialah deskriptif analitik dengan desain potong lintang. Responden penelitian ialah pekerja pemulung yang umumnya pada kelompok usia 18-45 tahun sebanyak 78 orang. Metode pengambilan sampel secara purposive sampling. Hasil penelitian menunjukkan pengetahuan responden tentang kesehatan gigi dan mulut dan status karies paling banyak ditemukan pada pengetahuan kurang dengan status karies tinggi yaitu sebesar 32,1\%. Berdasarkan uji Chi-Square didapatkan p value 0,027 ( $<<0,05$ ). Simpulan: Terdapat hubungan bermakna antara pengetahuan kesehatan gigi dan mulut dengan status karies pekerja pemulung di Tempat Pembuangan Akhir Sumompo Manado.
\end{abstract}

Kata kunci: pengetahuan kesehatan gigi dan mulut, pekerja pemulung, status karies

Pengetahuan kesehatan gigi dan mulut merupakan hal yang sangat penting dalam menunjang perilaku untuk menjaga kebersihan dan kesehatan gigi dan mulut. Meningkatnya pengetahuan seseorang akan memengaruhi kemampuan orang tersebut dalam menerima dan merespon informasi.
Semakin baik tingkat pengetahuan seseorang maka kemampuan untuk memiliki sikap serta perilaku akan semakin baik. Pengetahuan yang baik akan berdampak pada perilaku yang sehat, sebaliknya pengetahuan yang kurang merupakan salah satu faktor terjadinya 
masalah kesehatan gigi dan mulut. ${ }^{1,2}$

Kesehatan gigi dan mulut merupakan satu kesatuan dari kesehatan tubuh yang harus kita pelihara kesehatannya. Kesehatan gigi dan mulut masyarakat Indonesia masih jauh dari harapan, menurut data dari World Health Organisation (WHO) dalam The World Oral Health Report bahwa penyakit gigi dan mulut masih diderita $90 \%$ penduduk Indonesia. ${ }^{3}$ Salah satu penyakit gigi dan mulut yang paling banyak diderita masyarakat Indonesia ialah karies gigi. Berdasarkan data Riset Kesehatan Dasar (RISKESDAS) tahun 2013 menyebutkan bahwa prevelensi karies melalui pemeriksaan Decayed Missing Filled Teeth (DMF-T) untuk ratarata menunjukkan $25,9 \%$ masyarakat Indonesia memiliki masalah kesehatan gigi dan mulut, dan untuk provinsi Sulawesi Utara rata-rata $31,6 \%$ sehingga Sulawesi Utara berada di urutan kelima dari 34 provinsi di Indonesia yang memiliki masalah kesehatan gigi dan mulut. ${ }^{4,5}$

Tempat pembuangan akhir (TPA) Sumompo merupakan daerah yang dikhususkan untuk membuang sampahsampah yang ada di kota Manado. Kehidupan sosial ekonomi masyarakat di TPA Sumompo masih di bawah garis kemiskinan, dengan kondisi lingkungan yang cukup memprihatinkan, makanan yang kurang higienis, air yang kurang bersih, menyebabkan pekerjaan memulung memiliki risiko yang sangat tinggi terkena penyakit.

Penelitian yang telah dilakukan oleh Mustikawati ${ }^{6}$ tahun 2012 di Bandung yang dituangkan dalam jurnalnya, salah satu penyakit yang paling banyak diderita oleh pemulung yaitu karies. Hasil penelitian ini menunjukkan bahwa kurangnya kesadaran diri masyarakat terutama pada pekerja pemulung.

Penelitian ini bertujuan untuk mendapatkan hubungan pengetahuan tentang kesehatan gigi dan mulut dengan status karies pada pekerja pemulung di tempat pembuangan akhir Sumompo (TPA) Manado.

\section{BAHAN DAN METODE PENELITIAN}

Jenis penelitian ini ialah deskriptif analitik dengan desain potong lintang. Penelitian ini dilakukan di TPA Sumompo, pada bulan Oktober 2016. Populasi penelitian ini ialah seluruh pemulung yang terdaftar di TPA Sumompo Manado berdasarkan survei awal berjumlah 346 orang. Metode pengambilan sampel yang digunakan ialah purposive sampling. Pengambilan data diperoleh menggunakan kuesioner dan pemeriksaan DMF-T. Hasil penilaian tingkat pengetahuan dikategorikan menjadi baik, sedang, dan kurang. Hasil pengukuran karies dikategorikan menjadi tinggi, sedang, dan rendah.

\section{HASIL PENELITIAN}

Penelitian ini dilaksanakan di Tempat Pembuangan Akhir (TPA) Sumompo Lingkungan III. Sumompo merupakan daerah pinggiran yang dikhususkan untuk menampung pembuangan sampah dari masyarakat Kota Manado.

Berdasarkan hasil penelitian didapatkan responden berjumlah 78 orang. Karakterstik responden dibedakan atas jenis kelamin, usia, pendidikan terakhir. Tabel 1 menunjukkan dari 78 responden $52(67 \%)$ yang berjenis kelamin perempuan dan $26(33 \%)$ berjenis kelamin laki-laki.

Tabel 1. Distribusi responden penelitian berdasarkan jenis kelamin

\begin{tabular}{|c|c|c|}
\hline $\begin{array}{c}\text { Jenis } \\
\text { kelamin }\end{array}$ & (n) & $(\%)$ \\
\hline Perempuan & 52 & 67 \\
\hline Laki-laki & 26 & 33 \\
\hline Total & 78 & 100 \\
\hline
\end{tabular}

Pada Tabel 2 distribusi responden berdasarkan kelompok usia yang paling banyak yaitu usia 36-45 tahun diikuti kelompok usia 18-25 tahun dan yang paling sedikit kelompok usia 26-35 tahun.

Pada Tabel 3 distribusi responden berdasarkan pendidikan terakhir, persentase paling banyak berada pada tingkat SD, diikuti dengan pendidikan terakhir SMP dan pendidikan terakhir SMA dengan selisih yang cukup banyak. 
Tabel 2. Distribusi responden penelitian berdasarkan kelompok usia

\begin{tabular}{ccc}
\hline $\begin{array}{c}\text { Usia } \\
\text { (Tahun) }\end{array}$ & (n) & $\mathbf{( \% )}$ \\
\hline $18-25$ & 18 & 23,1 \\
$26-35$ & 9 & 11,5 \\
$36-45$ & 51 & 65,4 \\
Total & 78 & 100 \\
\hline
\end{tabular}

Tabel 3. Distribusi responden penelitian berdasarkan pendidikan terakhir

\begin{tabular}{lcc}
\hline Pendidikan Terakhir & (n) & $\mathbf{( \% )}$ \\
\hline SD & 37 & 47,4 \\
SMP & 34 & 43,6 \\
SMA/SMK & 7 & 9,0 \\
Total & 78 & 100 \\
\hline
\end{tabular}

Data mengenai pengetahuan tentang kesehatan gigi dan mulut yang ditanyakan langsung dengan kuesioner dibagi menjadi tiga kategori yaitu baik, sedang, dan kurang. Tabel 4 menunjukkan distribusi responden berdasarkan tingkat pengetahuan. Persentase paling banyak berada pada pengetahuan kurang, diikuti dengan pengetahuan yang baik dan sedang.

Tabel 4. Distribusi tingkat pengetahuan responden

\begin{tabular}{ccc}
\hline Pengetahuan & $(\mathbf{n})$ & $(\boldsymbol{\%})$ \\
\hline Baik & 26 & 33,3 \\
Sedang & 23 & 29,5 \\
Kurang & 29 & 37,2 \\
Total & 78 & 100 \\
\hline
\end{tabular}

Gambar 1 menunjukkan responden penelitian dengan jenis kelamin perempuan paling banyak pada kategori pengetahuan baik dengan jumlah sebanyak 21 responden $(40,3 \%)$ dan laki-laki pada kategori pengetahuan sedang dengan jumlah sebanyak 11 responden $(42,3 \%)$.

Gambar 2 menunjukkan responden penelitian yang paling banyak ditemukan pada kategori pengetahuan kurang dengan kelompok usia 36-45 tahun sebanyak 22 responden $(42,1 \%)$.

Gambar 3 memperlihatkan diagram distribusi tingkat pengetahuan berdasarkan pendidikan terakhir responden. Dapat dilihat bahwa persentase tertinggi berada pada tingkat SD dengan tingkat pengetahuan kurang; pada tingkat SMP dengan tingkat pengetahuan baik; dan pada tingkat SMA dengan tingkat pengetahuan baik dengan selisih yang cukup banyak.

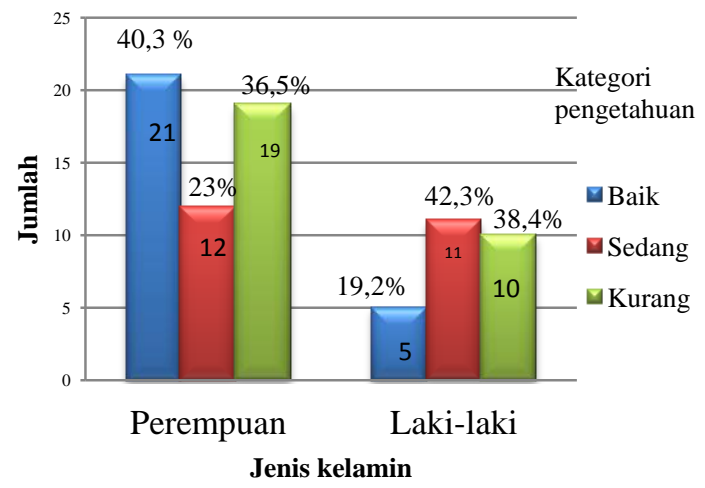

Gambar 1. Diagram berdasarkan jenis kelamin dan kategori pengetahuan

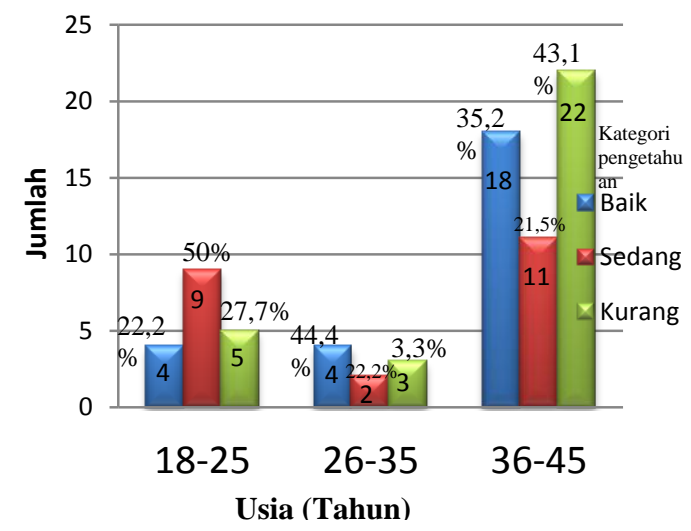

Gambar 2. Diagram berdasarkan kelompok usia dan kategori pengetahuan

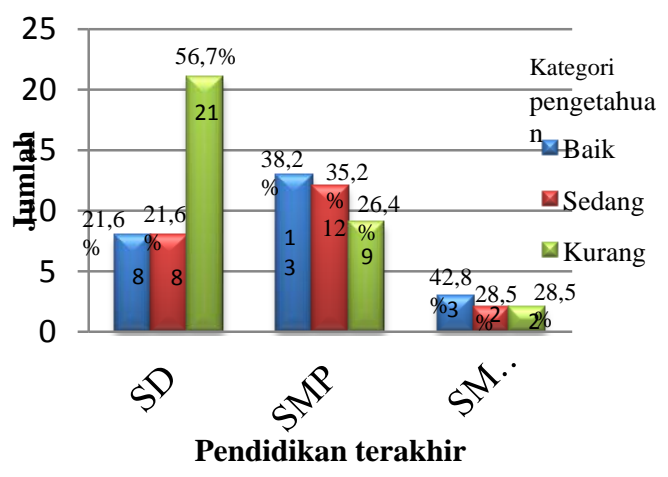

Gambar 3. Diagram distribusi tingkat pengetahuan berdasarkan pendidikan terakhir responden 
Data pemeriksaan status karies yang diukur dengan menggunakan DMF-T dikategorikan menjadi tinggi, sedang, dan rendah (Tabel 5 dan Tabel 6). Tabel 5 menunjukkan distribusi responden berdasarkan kategori status karies dimana kategori tinggi memiliki persentase paling besar diikuti kategori rendah dan sedang.

Tabel 5. Distribusi status karies responden

\begin{tabular}{ccc}
\hline Status karies & $(\mathbf{n})$ & $\mathbf{( \% )}$ \\
\hline Rendah & 14 & 17,9 \\
Sedang & 11 & 14,1 \\
Tinggi & 53 & 68 \\
Total & 78 & 100 \\
\hline
\end{tabular}

Tabel 6 menunjukkan distribusi responden yang paling tinggi pada jenis kelamin perempuan memiliki indeks DMFT sebesar 6,6 dan termasuk dalam kategori tinggi dan laki-laki memiliki indeks DMF$\mathrm{T}$ sebesar 6,3 yang termasuk dalam kategori tinggi.

Pada Tabel 7 dsitribusi responden berdasarkan kelompok usia 36-45 tahun memiliki indeks DMF-T paling tinggi sebesar 7,8 dan termasuk dalam kategori tinggi.

Pada Tabel 8 distribusi responden dengan pendidikan terakhir SD memiliki indeks DMF-T paling tinggi sebesar 7 dan termasuk dalam kategori tinggi di ikuti pendidikan terakhir SMP sebesar 6,5 dengan kategori tinggi dan yang paling rendah pendidikan terakhir SMA/SMK yang memiliki indeks DMF-T sebesar 5 dan termasuk kategori sedang.

Hasil analisis dengan menggunakan uji statistik Chi Square diperoleh nilai significancy $\mathrm{p}=0,027$. Hasil uji statistik ini menunjukkan nilai $\mathrm{p}<0,05$ maka, terdapat hubungan yang signifikan antara tingkat pengetahuan kesehatan gigi dan mulut dengan status karies pada pemulung.

Tabel 6. Distribusi indeks DMF-T responden berdasarkan jenis kelamin

\begin{tabular}{lccccccc}
\hline \multirow{2}{*}{ Jenis kelamin } & $\mathbf{n}$ & \multicolumn{3}{c}{$\begin{array}{c}\text { Komponen Indeks } \\
\text { DMF-T }\end{array}$} & $\begin{array}{c}\text { Total } \\
\text { DMF-T }\end{array}$ & \multirow{2}{*}{$\begin{array}{c}\text { Indeks } \\
\text { DMF-T }\end{array}$} & Kategori \\
\cline { 3 - 5 } & & $\mathrm{D}$ & $\mathrm{M}$ & $\mathrm{F}$ & & \\
\hline Perempuan & 52 & 197 & 147 & 2 & 346 & 6,6 & Tinggi \\
Laki-laki & 26 & 102 & 63 & 1 & 166 & 6,3 & Tinggi \\
Total & 78 & 299 & 210 & 3 & 512 & 6,5 & Tinggi \\
\hline
\end{tabular}

Tabel 7. Distribusi indeks DMF-T responden berdasarkan kelompok usia

\begin{tabular}{cccccccc}
\hline \multirow{2}{*}{ Usia (Tahun) } & $\mathbf{n}$ & \multicolumn{3}{c}{$\begin{array}{c}\text { Komponen Indeks } \\
\text { DMF-T }\end{array}$} & \multirow{2}{*}{$\begin{array}{c}\text { Total } \\
\text { DMF-T }\end{array}$} & $\begin{array}{c}\text { Indeks } \\
\text { DMF-T }\end{array}$ & \multirow{2}{*}{ Kategori } \\
\cline { 2 - 5 } & & $\mathrm{D}$ & $\mathrm{M}$ & $\mathrm{F}$ & & & \\
\hline $18-25$ & 18 & 30 & 30 & 0 & 60 & 3,3 & Sedang \\
$26-35$ & 9 & 23 & 29 & 1 & 53 & 5,8 & Tinggi \\
$36-45$ & 51 & 246 & 151 & 2 & 399 & 7,8 & Tinggi \\
Total & 78 & 299 & 210 & 3 & 512 & 6,5 & Tinggi \\
\hline
\end{tabular}

Tabel 8. Distribusi indeks DMF-T responden berdasarkan pendidikan terakhir

\begin{tabular}{cccccccc}
\hline $\begin{array}{c}\text { Pendidikan } \\
\text { terakhir }\end{array}$ & $\mathbf{n}$ & \multicolumn{3}{c}{$\begin{array}{c}\text { Komponen Indeks } \\
\text { DMF-T }\end{array}$} & $\begin{array}{c}\text { Total } \\
\text { DMF-T }\end{array}$ & $\begin{array}{c}\text { Indeks } \\
\text { DMF-T }\end{array}$ & Kategori \\
\cline { 3 - 5 } & & $\mathrm{D}$ & $\mathrm{M}$ & $\mathrm{F}$ & & & \\
\hline SD & 37 & 164 & 95 & 0 & 259 & 7 & Tinggi \\
SMP & 34 & 109 & 98 & 2 & 209 & 6,5 & Tinggi \\
SMA/SMK & 7 & 26 & 17 & 1 & 44 & 5 & Sedang \\
Total & 78 & 299 & 210 & 3 & 512 & 6,5 & Tinggi \\
\hline
\end{tabular}


Jurnal e-GiGi (eG), Volume 5 Nomor 1, Januari-Juni 2017

Tabel 9. Hubungan tingkat pengetahuan tentang kesehatan gigi dan mulut dengan status karies

\begin{tabular}{|c|c|c|c|c|c|c|c|c|}
\hline \multirow{3}{*}{$\begin{array}{c}\text { Tingkat } \\
\text { pengetahuan }\end{array}$} & \multicolumn{6}{|c|}{ Status Karies } & \multicolumn{2}{|c|}{ Total } \\
\hline & \multicolumn{2}{|c|}{ Rendah } & \multicolumn{2}{|c|}{ Sedang } & \multicolumn{2}{|c|}{ Tinggi } & \multirow[t]{2}{*}{$\mathrm{n}$} & \multirow{2}{*}{$\%$} \\
\hline & $\mathrm{n}$ & $\%$ & $\mathrm{n}$ & $\%$ & $\mathrm{n}$ & $\%$ & & \\
\hline Baik & 5 & 6,4 & 3 & 3,8 & 18 & 23,1 & 26 & 33,3 \\
\hline Sedang & 7 & 8,9 & 6 & 7,6 & 10 & 12,8 & 23 & 29,5 \\
\hline Kurang & 2 & 2,5 & 2 & 2,5 & 25 & 32,1 & 29 & 37,2 \\
\hline Total & 14 & 17,9 & 11 & 14,1 & 53 & 68,0 & 78 & 100 \\
\hline
\end{tabular}

\section{BAHASAN}

Pada penelitian yang dilakukan pada pekerja pemulung di Tempat Pembuangan Akhir (TPA) Sumompo Manado menunjukkan bahwa dari 78 sampel yang bersedia menjadi subjek penelitian pengetahuan kesehatan gigi dan mulut yang didapatkan dari pengisian kuesioner, persentase terbesar sampel yang diteliti berpengetahuan kurang yaitu berjumlah 29 orang (37,2\%). Angka yang diperoleh menunjukkan rata-rata pengetahuan responden dalam hal kesehatan gigi dan mulut tergolong kurang. Hasil penelitian ini serupa dengan penelitian yang dilakukan oleh Gultom $^{7}$ di Medan mengenai pengetahuan masyarakat khususnya pada pekerja pemulung yang memiliki persentase tertinggi dengan tingkat pengetahuan yang masih kurang. Hal ini disebabkan karena masih banyak responden yang belum menerima pendidikan yang layak dan tidak memiliki kesempatan belajar karena terbatasnya kemampuan ekonomi.

Persentase tertinggi berada pada tingkat SD dengan persentase $56,7 \%$ yang menunjukkan faktor pendidikan turut memengaruhi pengetahuan responden dibidang kesehatan gigi dan mulut. Hal ini sesuai dengan pernyataan Mubarak ${ }^{8}$ yaitu pengetahuan turut dipengaruhi oleh faktor pendidikan. Semakin tinggi pendidikan seseorang, maka semakin mudah untuk menerima informasi, dan pada akhirnya semakin banyak pengetahuan yang dimilikinya. Sebaliknya, jika seseorang memiliki tingkat pendidikan yang rendah maka akan menghambat perkembangan seseorang untuk memperoleh informasi atau pengetahuan yang disampaikan. Hasil ini juga serupa dengan penelitian Pinatauli ${ }^{9}$ di Kecamatan Medan Tuntungan menunjuk kan bahwa seseorang yang memiliki tingkat pendidikan rendah kemungkinan akan memiliki pengetahuan yang kurang mengenai kesehatan gigi dan mulut.

Status sosial ekonomi responden turut memengaruhi tingkat pengetahuannya. Hal ini didukung oleh pernyataan dari Setiadi ${ }^{10}$ yang menyatakan bahwa sosial ekonomi seseorang juga akan menentukan tersedianya suatu fasilitas yang diperlukan untuk kegiatan tertentu sehingga pengetahuan seseorang semakin baik.

Data hasil pemeriksaan status karies gigi yang diukur dengan menggunakan DMF-T menunjukkan bahwa sebagian besar subjek yang diteliti status karies tinggi yaitu berjumlah 53 orang (68\%). Hasil ini juga serupa dengan penelitian yang dilakukan oleh Mustikawati $^{6}$ di Bandung mengenai personal hygine yang menyatakan penyakit yang paling banyak diderita salah satunya yaitu karies. Hal ini disebabkan karena status sosial ekonomi dan latar belakang tingkat pendidikan yang rendah, kecendrungan untuk tidak merawat gigi yang benar serta tidak ada tenaga kesehatan yang memadai selain itu, terdapat faktor luar sebagai faktor prediposisi dan menghambat yang berhubungan tidak langsung dengan terjadinya karies gigi antara lain usia dan jenis kelamin yang dapat dilihat dari karakteristik responden.

Hasil pemeriksaan karies berdasarkan jenis kelamin menunjukkan bahwa DMF-T lebih tinggi pada jenis kelamin perempuan dibandingkan jenis kelamin laki-laki. Hal 
ini disebabkan pertumbuhan gigi perempuan lebih awal dari pada laki-laki sehingga masa terpajan dalam mulut lebih lama serta dipengaruhi oleh perilaku pemeliharaan dan asupan makanan. ${ }^{11}$

Hasil pemeriksaan karies berdasarkan kelompok usia yang paling banyak pada kelompok usia 36-45 tahun yang mengalami karies dengan kategori tinggi. Usia responden dari hasil ini menunjukkan masih tergolong usia produktif sehingga aktifitas yang padat dari pekerjaan yang dimiliki dapat memengaruhi kondisi kesehatan rongga mulut. Hasil ini serupa dengan penelitian yang dilakukan oleh Notohartojo dan Ghani ${ }^{12}$ pada beberapa kelompok usia di Kalimantan Barat tahun 2015 bahwa sampel yang paling banyak yaitu berusia 36-45 tahun.

Hubungan pengetahuan kesehatan gigi dan mulut dengan status karies menunjukkan persentase yang paling tinggi yaitu responden yang mempunyai tingkat pengetahuan kurang dengan status karies tinggi berjumlah 25 orang $(32,1 \%)$. Hasil uji statistik menggunakan uji Chi Square menunjukkan adanya hubungan antara tingkat pengetahuan tentang kesehatan gigi dan mulut dengan status karies pada pemulung $(\mathrm{p}=0,027)$. Hal ini memperlihatkan bahwa pengetahuan yang baik tentang kesehatan gigi dan mulut sangat penting dan berpengaruh positif terhadap sikap dan tindakan pemeliharaan kesehatan gigi dan mulut. Kebersihan gigi dan mulut dilakukan untuk mencegah penyakit gigi dan mulut, memperbaiki fungsi mulut untuk meningkatkan nafsu makan dan meningkatkan daya tahan tubuh. ${ }^{13}$

\section{SIMPULAN}

Berdasarkan hasil penelitian ini dapat disimpulkan terdapat hubungan bermakna antara pengetahuan tentang kesehatan gigi dan mulut dengan status karies pada pekerja pemulung,

\section{SARAN}

Disarankan kepada pemerintah dan klinisi setempat agar lebih memerhatikan derajat kesehatan gigi dan mulut pada pekerja pemulung dengan penyuluhan dan sosialisasi tentang kesehatan gigi dan mulut, serta meningkatkan kegiatan pemeliharaan kesehatan gigi dan mulut pekerja pemulung, misalnya pemeriksaan gigi rutin.

\section{DAFTAR PUSTAKA}

1. Notoatmodjo S. Promosi Kesehatan dan Ilmu Perilaku. Jakarta: Rineka Cipta, 2007; p.133-51

2. Budiharto. Ilmu Perilaku Kesehatan dan Pendidikan Kesehatan Gigi. Jakarta: EGC, 2010; p.1-5, 18-9.

3. Poul PE. The world oral health continouns improvement of oral health in the $21^{\text {st }}$ century. Geneva, Switzerland: 2012. p. 3-5. Available from: http://www.who.int/oral_health/medi a/en/orh_report03_en.pdf

4. Thahja N, Sintawati F, Yovita. Gambaran karies gigi permanen di beberapa puskesmas kota dan kabupaten. Litbang Kesehatan XVI nomor 4. 2004. Available from URL: http://ejournal.litbang.depkes.go.id/in dex.php/MPK/article/download/1133/ 492.

5. Badan penelitian dan pengembangan kesehatan. Departemen kesehatan RI. 2008. Laporan hasil riset kesehatan dasar gigi dan mulut 2013

6. Mustikawati IS. Perilaku personal hygiene pada pemulung di TPA Kedaung Wetan Tangerang. Jurnal Universitas Esa Unggul. Jakarta. 2012. Available from:

URL: http://digilib.esaunggul.ac.id/public/U EU-Journal-4522-Intan.pdf

7. Gultom R. Pengetahuan dan sikap pemulung dengan tindakan dalam personal hygiene di desa Maindal I kecamatan Patumbak Medan. Jurnal UI. 2012;5(2).

8. Mubarak WI. Promosi kesehatan. Yogyakarta: Graha Ilmu, 2007; p.145.

9. Pinatauli S, Melur T, Hubungan tingkat pendidikan data skor DMF-T pada ibu-ibu rumah tangga berusia 20-45 tahun di Kecamatan Medan Tuntungan. Jurnal Dentika Dent. 2004;9:78-83.

10.Setiadi. Ilmu Sosial Budaya Dasar. Jakarta: Perdana Media Grup, 2002. 
11.Saima A, Saleem M, Mohtada H, Fatima I. Distrinution of dental caries and its relationship to risk factors. Pakistan oral \& dental journal. 2011. [cited 2016 Nov 12]. p.453-6. Available from URL: http://www.podj.com.pk/Dec_2011/5 2-Podj.pdf

12.Notohartojo IT, Ghani L. Pemeriksaan karies gigi pada beberapa kelompok usia oleh petugas dengan latar belakang berbeda di Provinsi Kalmantan Barat. Buletin Penelitian Kesehatan. 2015;43(4):257-64.

13.Prashant ST, Bhatnagar S, Das UM, Gopu H. Oral health knowledge, practice, oral hygiene status and dental caries prevalence among visually impaired children in Bangalore. Journal of Indian Society of Pedodontics and Preventive dentistry. 2011;29(2):102-5. 